\title{
Variety, flexibility and autonomy: Intrinsic rewards of teacher-librarianship
}

Esser, Linda $\mathrm{G}$

International Association of School Librarianship. Selected Papers from the ... Annual Conference; 2001; Education Database

\section{Variety, Flexibility and Autonomy: Intrinsic Rewards of Teacher-Librarianship}

\author{
LINDA G. ESSER \\ School of Information Science and Learning Technologies, \\ University of Missouri-Columbia 65211, \\ United States of America \\ esserL@missouri.edu
}

\begin{abstract}
This study explored the initial motivations and intrinsic rewards of eighteen women who chose to become elementary school teacher-librarians. Participants' initial motivations were consistent with those of their classroom teacher-colleagues in most areas examined by the study. However, participants indicated three initial motivations or intrinsic rewards that appear specific to teacher-librarianship: variety, flexibility and autonomy. Participants' stories provide insight into how they view their work and how they negotiate work relationships with their classroom teacher-colleagues, and negotiate for autonomy in the workplace.
\end{abstract}

\section{INTRODUCTION}

The United States is facing a critical shortage of teacher-librarians. Insufficient qualified personnel in over half the states have forced school administrators to hire noncertified staff, rely on parent or community volunteers, or dismantle library media programs entirely (Everhart, 2000). Given this context, it is important to understand the factors that initially attract individuals into the profession, and the intrinsic rewards in-service practitioners experience that sustain their commitment to teacher-librarianship. This study explores the motivations of eighteen women who choose to become members of the profession.

Clearly, librarianship, particularly teacher-librarianship, is a female-intensive profession. In 1995, one out of five persons awarded the degree of Master of Library Science in the United States accepted positions connected to youth services in public or school libraries. Of that number, the majority of those who accepted positions related to work in youth services in libraries were women: $94 \%$ in public libraries; $92 \%$ as teacherlibrarians (Zipkowitz, 1995).

In Kentucky, where this study was located, the highest proportion of women who are teacher-librarians carry out their work in elementary school settings. A statewide analysis of school staffing for the 1994-1995 academic year (Bank, 1994) reveals that, in secondary schools, approximately $97 \%$ (216 of 222) of teacher-librarians were women; in middle schools, $95.5 \%$ (178 of 186); and in elementary schools, $99.4 \%$ (619 of 622). These statistics are likely to be similar in other states, with the substantial majority of female teacher-librarians in positions at the elementary school level.

The literature of teacher-librarianship is rich with research on aspects of teacherlibrarians' work but says little about the women who carry out that work (Hannigan, 1994). 
Through collecting life history narratives, this research seeks to disrupt some of the silences in the literature about women who are practicing teacher-librarians. Rather than decontextualizing their work, this study seeks to understand these women's work, the meaning they give to their work and the place of their work in their lives. Hug suggests it is this meaning, or the ways that teacher-librarians interpret this meaning that "determine what constitutes legitimate activity in the media center and are a critical issue in regard to the role of the school library media specialist" (Hug, 1981, p. 52).

\section{RESEARCH METHODS}

\section{Margaret}

My mother, I think, has always been a reader...and my father read and everyone in the house read so it was just a way of life...There wasn't a great deal of money because my mother didn't work. My father had just come back [from military service] and didn't have a college degree and so that was our entertainment. You went to the library. You got books. You sat around and read. It was very, very positive and that probably instilled a large part of what I am today.

My mother didn't work at the time. I was five when she went back to work. We would all get in my little red wagon... and we'd walk about five blocks to the library and that was our big outing. Once a week, we'd go up there, check out books and brought them home with us... There's probably a bonding thing with my mother because it was...the time the other two [children] were in school and it was our special time together.

Margaret also remembers the public librarian at the small, neighborhood branch library who helped her find books about her favorite topic, cats.

I can picture her. She knew I loved cats. I'd walk around the neighborhood calling, "Kitties, kitties, are there kitties around?" I'm sure I was an embarrassment to my family but I loved cats...She was an elderly lady and she had gray hair... and she would show me cat books when I came in. She knew just what I liked to read.

Margaret's story is a vignette from one of eighteen life history narratives collected from women who were elementary teacher-librarians in Kentucky during July 1996 through June 1997. Personal, oral narratives collected through interviews are "the vehicle of choice both in capturing the ways that people actually constitute self-knowledge and in soliciting them to convey personal meaning along a temporal or sequential dimension" (Huberman, 1995, p. 130). Six of the teacher-librarians who were interviewed worked in city schools, six in commuter shed schools and six in rural schools. Participants in the study represented the state's three distinct cultural and geographic regions.

Data was gathered for this study through in-depth phenomenological interviews. Three overarching questions provided a framework for the interviews and were asked of each participant.

Question One (reviews the participant's life history before she became an elementary school teacher-librarian): Tell me as much as you can about your life before you became an elementary school library media specialist. 
Questions Two (contemporary experience): What is it like for you to be an elementary school library media specialist? Tell me about a day in your life from the time you wake up until the time you fall asleep.

Question Three (giving meaning to the work): Given what you have said about your life before you became an elementary school library media specialist and given what you have said about your work now, what is the place of your work in your life? What meaning does your work have for you?

A subset of questions was developed for each of the overarching questions. Use of the subset questions varied from participant to participant, depending upon the extent of the response to the overarching questions.

Interviews were audiotaped and transcribed verbatim; then converted to The Ethnograph for data analysis. A sampling analysis technique was used to develop a system for working with 1600-plus pages of text-based data. Three representative interviews, one each from the categories of central city, commuter shed and rural, and representative of each geographic region were selected. Using the sampled transcripts, coding categories were developed to identify passages of interest. The remaining transcripts were then sorted into sets of three applying the same criteria used to assemble the sampling, then analyzed and coded. In this way, cultural differences related to region, and professional practice differences related to school location did not become commonplace. Instead, each transcript provided a regional and location contrast to its predecessor.

The initial set of codes proved to be too fragmented to be particularly useful. These fragmented codes were collapsed into broader categories. In coding the data, efforts were made to retain some contextual framework or setting for each story. Three central themes emerged from the data:

- the intersection of identity and work,

- negotiating relationships in the workplace,

- negotiating relationships beyond the workplace.

This paper will focus on the first central theme, the intersection of identity and work.

Intersection of identity and work gathers those stories from the narratives where the identities of the participants as teacher-librarians and their identities as women intersect. In this category are the participants' stories of women and men (predominantly women) who significantly influenced their decisions to enter the field of education and/or librarianship. The intersection these also includes stories of the aspects of the work the participants find particularly rewarding.

\section{Intrinsic Rewards of Teacher-Librarianship}

Lortie (1975) classified the rewards of teaching into three distinct categories; extrinsic, ancillary and psychic or intrinsic. Extrinsic rewards are those considered to have an objective quality and that are independent of the individual, such as salary. Ancillary rewards are those that may be simultaneously subjective and objective. For example, women might consider the work schedule of the teaching profession to be an ancillary reward while men might not. Psychic rewards, those that are subjective in nature, vary from 
individual to individual. These rewards are centered in the nature of the profession and its work. While there is substantial variation in the psychic or intrinsic rewards that accrue to individuals, it is important to discover these intrinsic rewards that recur across individuals and to understand the contexts that produce these rewards.

The participants' initial motivations for choosing to become educators, whether their initial certification was as a classroom teacher or a teacher-librarian, appear to be consistent with those identified in the literature (Biklen, 1995; Huberman \& Grounauer, 1993; Lortie, 1975). These motivations include, among others, finding pleasure in the culture of school and schooling, love of the subject matter (books/reading), working with children, role models, humanitarian ideals, financial security and stability, and a work schedule that is conducive to the blending of work and family. While Huberman and Grounauer (1993), and Lortie (1975) are problematic concerning the female-intensive nature of teaching, these studies, along with Biklen (1995), prove helpful in providing a framework for thinking about the attractions and intrinsic rewards of teaching and teacher-librarianship described by the participants.

\section{Initial Motivations}

Love of books and reading emerged as a primary initial motivation for seventeen of the eighteen participants. Participants related stories similar to that of Margaret's related earlier in this paper, stories of visits to the public library, of parents and older siblings who read aloud in the evenings, of family trips to the library each Saturday.

I've always loved to read.... When I was growing up and lived out in the country... we had just one vehicle and my father took it to work except [when] we would go into town once a week. There wasn't a whole lot to do, so we would go to the library and I would check out ten or twelve books and come home. I just loved to read. I've always enjoyed reading. [Ann Marie]

I can remember in the fourth grade searching around for things to read [and finding] the encyclopedias, the story parts of the encyclopedias. [Ruth]

I was the one who always walked around with a book in her hand.... When my children were young, I went with my mother to the shoe store.... They used to buy my shoes there when I was growing up and we took my children to get shoes. When she told one of the salesmen who I was, he said, "Oh, that was the one who always brought a book." [Jane]

The influence of female role models on the participants' decisions to enter teaching and teacher-librarianship are significant. Recall Margaret's story of the public librarian who worked in the local branch library and who cared enough to remember the kinds of books Margaret liked best are very distinct. Whitney, too, has clear memories of a public librarian who played a significant role in her young life.

The little public library was about three or four doors up from me...I would go up and help her... and she let me put books away. I guess that stayed in my mind all those years. I can't tell you what she looks like. I can't tell you anything about her, other than the fact that she took an interest in me...I'd go to the library any time I wanted to after school, if I wasn't with friends. That lady was probably one of the most influential people [in my life]. [Whitney] 
Ruth vividly remembers the year she was in seventh grade and a "remarkable lady" came to teach at her school.

I remember that year they had hired several new teachers...to teach the seventh and eighth grade students.... The teacher...I had was a lady who had just graduated from the university and was still doing her master's work...in library science. She had a classroom and taught seventh grade but she'd been hired to start a library in the school. She brought a lot of her own books from her collection at home and we started building shelves around the wall in our [class]room. That's where the library and the concept of the library really became a reality for me. [Ruth]

For many of the participants, female role models were found much closer to home. Fourteen of the eighteen women interviewed spoke of immediate family members who became teachers or librarians. Seven of the participants are second generation teachers or librarians.

One was the fact that my mother was a teacher...and I saw that she was home with us kids...during the summer. She was home with us during the evening. And I knew that I wanted to have kids, and I wanted my family to be a high priority, too, and that was a good career for that. Teaching is a good career to have a family with. The other thing...[was] my first grade teacher was just so influential. [Jeanette]

I guess education came naturally because my mother had been in it... from the time she finished her degree. I knew that my mother was making a good living. I knew that the schedule would be good for a family. So I think that led me toward education. Even though it's a hard job, the timing works well for a family....You're home right at the time they're [the children] home. If they came home on the bus, you were right behind them or right in front of them usually. And so I think that the hours for a family kind of drew me that way. Because I knew that I could have summertime with my kids. I knew that other careers that I had seen did not offer anything like that. [Whitney]

Other participants considered the blending of family and work life as an initial motivation.

This was really a strong point you know. It's really neat to have part of your summer home, so maybe that was, at that point in time, maybe that was a selling point. [Amanda]

To be honest....the hours that I teach.... and being off during the summer appealed to me. Looking down the road, thinking of being a wife and mother, that was appealing. [Ann Marie]

Some of the participants enjoyed school and schooling, and the rhythm of the academic year. They do not recall ever making a definite decision to enter teaching or teacher-librarianship.

It was just something I was always going to do. I think the idea [was] ...to get into a school library and it never entered my mind...to go into...some other field of librarianship. [Suzanne]

The very first day of first grade I knew I wanted to be a teacher. I just loved kids, loved the teacher, just thought school was wonderful, so I knew I wanted to teach. [Anna] 
I loved school....I was one of those students that, when they talked about...going back [to school] again, the excitement of getting that notebook and that paper and those pencils and starting back again...I wanted to go back. I didn't want to be away from it. [Anita]

\section{INTRINSIC REWARDS OF TEACHER-LIBRARIANSHIP}

\section{Variety and Flexibility}

Participants indicated additional initial motivations that appear to be specific to teacher-librarianship. Six of the eighteen participants commented that they were attracted to teacher-librarianship because of motivations that relate to the variety of activities that are part of the work. One participant commented that, for her, flexibility was a significant motivation; two participants spoke of motivations related to both variety and flexibility.

Three of the participants used the term variety to describe their motivations for entering teacher-librarianship.

I decided I needed another change, so the library started looking pretty good because I still loved to read and enjoyed what I did with the kids [as a teacher]. I enjoyed taking the kids to the library and using it with them. So I thought, well, the library would allow me to use my music background, and allow me to use my classroom [teaching] and allow me to do a variety [italics added] of things. So that's where I stopped. [Anna]

Just having the variety [italics added] that goes into the job. The fact that it just dovetailed so nicely with some of the other things that I really enjoyed. [Sidney]

If I were going into education, thinking back on it, then I wanted to be able to have variety [italics added] in my life. I don't feel that I would be comfortable with a class locked in a classroom all day long. [Whitney]

While they do not specifically use the term variety as a descriptor, several participants describe two or more kinds of activities related to the work.

I like the administrative types of things. It also allowed me to do some of that, too, without the overwhelming responsibilities that being a principal [would entail]...I liked the literary aspect of the library. I liked the technology aspect of the library. I liked the fact that it was never the same two minutes in a row. [Jeanette]

I've always loved libraries. I love library work. I'm an orderly kind of person. I'm an organizer. I like putting those books on the shelves. I like getting things in order. That part has always appealed to me. I've always been curious, always wanted to know things. So I think that part of library work always appealed to me, too. I like hearing the question that somebody needs an answer for and trying to find it. [Margaret]

Getting to deal with different faces everyday. Not having the same group of people looking at you every morning, expecting you to put on a show would be one way of saying it....I had originally thought I wanted to go into secretarial work and I get to do some of that, too. So that was an attraction. Then, of course, I like sharing stories with kids.... [Marla] 
I love the administrative aspect of it. I love the literature aspect of it. I enjoy the technological aspect of it. I like the fact that I work with many different types of people all day long, students of all ages, all different types of teachers, and that appeals to me rather than being with the same people all day long. I just like library work and all the differences, and coming in every day and not knowing what you're going to be doing. It's just real challenging and I think it would be a different type situation in a classroom. [Martha]

Variety, then, would seem to describe a category of motivations related to the serendipitous nature of the teacher-librarian's work. The participants perceive their work as different from classroom teaching in that library work is less static and predictable. This is Jeanette's "never the same two minutes in a row."

The daily work activities of teacher-librarians do provide variety. In addition to teaching, there is reference work, the kind of work Margaret enjoys so much. Teacherlibrarians perform extensive administrative functions that include planning, managing a budget, working with technology and collection development. The scope of the work is as broad or limited as individual teacher-librarians conceive it to be.

Flexibility is more problematic. Only Ellen used the term, flexibility, to describe the attractions of the work.

I like being able to sort of do what I want to do. Of course, there are limits and guidelines, but I still sort of get to do what I want to do. There's something about the flexibility [italics added] that's more attractive to me than being stuck...in a classroom. [Ellen]

Three participants spoke of motivations markedly similar to Ellen's.

I recognized that a librarian has some more independence [than a classroom teacher]....A classroom teacher has almost no ability to say, "no," not that I do exactly, but there's just some more independence and I don't like being without choices. [Julia]

...the fact that you worked part of the time with the children and part of the time with administrative functions.... really think a lot of the attraction was the fact that I'd still be with the children but I'd have some time to do other things, too. [Jane]

I like the freedom that I have to kind of select what we do...I had a teacher tell me that she envied the freedom that I have, especially with KERA!. She felt like she was boxed into having to do certain things. She appreciated the fact that $I$, although [I] work in supplementing what they [classroom teachers] do and what the school does, that I can choose what I want to do. [Hazel]

Flexibility, as used by Ellen, indicates having a degree of control over the kinds of work carried out by the teacher-librarian and the scheduling of that work. This fits with Julia's "independence" and the ability to make choices in how she constructs her work.

Jane talks about both variety and flexibility. There is variety in working with children and administrative responsibilities, two very different kinds of broadly conceptualized activities that would both lend themselves to a wide range of more narrowly defined aspects of the work. In her narrative, Jane also comments that, although she thought 
that most of her time would be filled by her work with students and her administrative duties, she anticipated "some time to do other things, too." Her choice of words suggests that Jane felt she would exercise some measure of control over the kinds of work she chose to do during that time.

Like Julia and Jane, Hazel also values exercising some measure of control over her work. She refers to this measure of control as having "freedom" to make choices, using language strikingly similar to Julia's. Interestingly, Hazel's work is perceived by one of her teacher-colleagues as being less " boxed in," less proscribed than the daily routine of the classroom.

Then, why is the term, flexibility, problematic? The participants collectively give two separate and distinct meanings to flexibility through their use of the term in their narratives. These are 1) having some degree of control over one's work activities, and 2) the ability to move rapidly from one work activity to another. Brenda's use of flexibility illustrates the second meaning.

I guess that my keyword is flexibility because you've got to be ready to move on a moment's notice.

Careful reading of the previous texts used to illustrate the two meanings helps resolve the issue. The texts of Ellen, Julia, Jane and Hazel are not about flexibility. Rather, these texts are about autonomy. These women construct autonomy as having freedom from bureaucratic strictures and a measure of control over one's work. This is Ellen's "get to do what I want to do," Julia's "more independence" and "choices," Jane's "some time to do other things" and Hazel's "the freedom that I have to...select what we do." Here is the ability to make choices, to exercise independence and freedom, to be autonomous.

\section{Autonomy}

One of the most overworked terms in the education reform movement is "teacher empowerment". At the national, state and local level, the demand for increased accountability and the implementation of high-stakes assessment practices increasingly orchestrate teachers' work and daily activities. "Work culture," comments Lamphere, "is only relatively autonomous; it emerges in relation to management strategies" (Lamphere, 1985, p. 522).

Greater governmental control and intervention reserves the right to make curricular decisions to the state, essentially wresting these decisions from the control of classroom teachers. In many ways, the strides teachers have made over the past decades to gain some measure of control over their work are being rapidly eroded. When teachers no longer control the substance of their work, they lose autonomy. (Hargreaves \& Fullan, 1992).

Autonomy is usually equated with greater individual independence, a kind of distancing from relationships with others (Apple, 1986; Lortie, 1975). However, Biklen (1995) suggests that "being in-relations is not the opposite of autonomy" (p. 105). She draws this conclusion from her study of contemporary women teachers.

These teachers did not envision autonomy taking them away from connections to others, but they did not want to be subject to bureaucratic authority; they struggled 
for the freedom (and responsibility) of negotiating decisions about their work (Biklen, 1995, p. 95).

Analysis of the narrative data would seem to support Biklen's statement. Participants who told stories of having negotiated successful working relationships with their classroom teacher colleagues seemed to experience a greater degree of autonomy in their work. Anna is an example of a teacher-librarian who has carefully constructed and nurtured relationships with her classroom teacher colleagues.

I think you have to know the people that you work with and there are times that if I tell a team...I'll say, I'd really like to meet with your team, you have...your planning time tomorrow at 9:10...Usually, if I'm going to do that, I give them a week ahead of time so that they know I'm coming. I find that usually better received, if I meet infrequently, and not at that [planing] time. Because usually that's when they're planning to run off what they need for the next day, or they're planning to do this, or they've got conferences...So I have to be very judicious. And if I know that a particular person holds that time in reserve for his or her own things, then I'll catch them when I can. I don't mean to imply that I don't ever plan with them as a group, because I do. But it's just [that] I find that a lot of people hold that time so jealously that I don't want to create bad feelings. [Anna]

In return, Anna's teachers respect her unique contribution as one of the very few members of the instructional team who works with all of the students in the school, all of the faculty and the administration.

So there's a lot of trust...by the faculty....people say, "Well, you're inside. You're role is vital to what we're doing. I couldn't do curriculum without someone who sees the whole group, the whole range K-5." And no matter the areas, whether it's science, or social studies, special areas, art, music, whatever. It's just a similar range and the total picture. I think people value what I have to offer and that's a validation for me. [Anna]

Brenda works in a small school supported by limited funding. She took the initiative and lobbied for flexible scheduling, then negotiated with her classroom teacher colleagues for its implementation.

The first year was kind of rocky because...I was a break for them [the teachers] at one time... That was part of their planning time when I did the scheduling [regularly scheduled classes] and it was a little bit different for them but I think they like it now. I don't think they would ever go back to...scheduled [classes]...

Sometimes, I'll tell the teachers, "I want your kids. Merry Christmas. Go have a break or something" and Ill take the kids...because I want to do something with them...Now I don't do that all the time because then it would get back into the routine [of fixed scheduling]. But I do like to do that occasionally.

They say a lot of good things to my face-I mean to other people in front of meand I don't think it's just lip service. I have a good working relationship with my faculty. I think they feel very, very comfortable coming in here [the library media center]...I just think they think I'm a valuable person. I've always had support from them in anything I've done. [Brenda] 
Ellen is employed as a part-time teacher-librarian by the school district. She has experienced difficulty negotiating working relationships with her classroom teacher colleagues.. She is not required to begin the school day at the same time as her classroom teacher-colleagues. Legitimately, she arrives a little later in the morning after having dropped her children off at their school on her way to work. Ellen comments that her teacher-colleagues and administrator seem to forget she is part-time. These circumstances create an atmosphere of antagonism, blame and confrontation, barriers to negotiating the relationships necessary to successfully implement the library media program.

It starts the second I walk in the door and it is non-stop until I leave there. Teachers coming in, "Well, I was trying to get this [item] this morning and you weren't here."...I really feel like they still don't know that I don't get here until a little later in the morning because it seems like the gist of the question is, "Where were you?"

I think that they think that I don't do anything, for the most part....That is the impression that I get...I can tell that by putting up with stuff throughout the day like a student will come and say "Ms. So and So needs twelve copies of this." Excuse me? I don't make copies for teachers.... They seem like they have no concept whatsoever of what I am doing and granted, that is not true for the whole building, because there are a handful of those who have actually ventured and asked, "Do you have this?" or "Can you help me find that?"....For the most part, I don't think they respect me, though. I think they see my job as a place where their children go for their [the teachers] planning. I hate it that I feel that way, but I do because that's the impression that they give. [Ellen]

Ellen is working to establish collaborative planning and teaching relationships with her classroom teacher-colleagues. However, she feels that, while mandated by her administrator, her efforts have met with overt resistance from the classroom teachers.

Zero. It's always on my evaluation, need to do more collaborative teaching...I have told my principal before, all they [the teachers] have to do is come and tell me.....No, he says, you need to go tell them. Well, I can't just go tell them what to do, which is the way that I think that they would perceive that, as someone messing with their territory. [Ellen]

Both Anna and Brenda have a substantial measure of control over their work. Anna initiates scheduling planning meetings with her classroom teacher colleagues, mindful of their responsibilities and needs. Brenda persuaded the teachers she works with to support the implementation of flexible access scheduling. As part of the agreement, teachers remain with their students in the library media center to assist with instruction and research activities. In contrast, scheduled classes and resistant classroom teachers dominate Ellen's work as a teacher-librarian. Ellen's relationships with her classroom teacher colleagues are strained and ineffective, lacking the quality of "being in relations" described by Biklen. She has marginal control over her work, if any. Her perception of how she is regarded by the teachers with whom she works is markedly different from the experiences of Anna and Ellen as are the corresponding levels of satisfaction with their work.

\section{CONCLUSIONS AND RECOMMENDATIONS}

This study explored the participants' initial motivations for becoming teacherlibrarians, factors that almost certainly influence how they construct professional practice. 
With one exception, the participants describe themselves as avid readers from early childhood. Several of the participants spoke of prior positive experiences in libraries of one kind or another. Some assisted librarians in various ways, checking out books, like Elizabeth in a school library, and helping peers select books like Whitney in the local public library. Others recall special relationships with librarians like those described by Ruth and Margaret.

Variety, flexibility and autonomy are significant motivations for some of the participants in making the decision to become teacher-librarians. The degree of autonomy experienced is directly related to the degree of control exercised by agencies in positions of power over classroom teachers and teacher-librarians. Biklen suggests that 'being in relations" enables autonomy rather than constraining it.

These conclusions suggest possibilities for future research. Love of reading was a key initial motivation for seventeen of the eighteen participants. In a profession where technology is increasingly prominent and activities related to reading are often eclipsed by the demands of technology, what is the effect of this transition on recruitment for the profession? Do the increased demands for expertise in technology act as a negative motivation?

How do childhood or adult experiences with libraries and librarians influence the initial motivations of teacher-librarians? Is there an informal cognitive apprenticeship that takes place in some circumstances and, if so, what are the circumstances and what does that apprenticeship look like?

How prevalent are the motivations of variety, flexibility and autonomy? How does the work of teacher-librarianship provide greater variety, flexibility and autonomy than the work of classroom teaching? This study needs to be replicated and the distinction between initial motivations and intrinsic rewards should be refined.

Research in teacher-librarianship must begin to explore the profession as one that is female-intensive and situate the research in the wider world of women and work. There is much to be learned from the ways women negotiate relationships in the workplace. It is essential to acknowledge that it is women who negotiate with each other to form instructional partnerships and to place this issue at the center of research on teacherlibrarians rather than the periphery or ignore the fact entirely.

To understand how the participants' explain their work and the place of their work in their lives is to better understand the meaning they give to their work and the ways they translate that meaning into professional practice. The participants' stories provide insight into how they view their work and how they negotiate work relationships with their classroom teacher-colleagues. It is the shape and texture of these relationships that forms the substructure of successful professional practice. The negotiation process is highly complex and multi-dimensional. It is women negotiating relationships with women, negotiating for a share of power, prestige and control, negotiating for autonomy in the work place.

'The Kentucky Education Reform Act of 1990.

\section{NOTES}


Table 1

\section{Participant Data Chart}

\begin{tabular}{|c|c|c|c|c|c|c|c|}
\hline $\begin{array}{l}\text { Participant } \\
\text { Pseudonym }\end{array}$ & $\begin{array}{c}\text { Age } \\
\text { Category }\end{array}$ & $\begin{array}{c}\text { Current } \\
\text { Marital } \\
\text { Status }\end{array}$ & Children & $\begin{array}{c}\text { Experience as a } \\
\text { Classroom } \\
\text { Teacher }\end{array}$ & $\begin{array}{c}\text { Experience as a } \\
\text { Teacher- } \\
\text { Librarian }\end{array}$ & $\begin{array}{c}\text { Level of Initial } \\
\text { Certification as a } \\
\text { Teacher-Librarian }\end{array}$ & $\begin{array}{c}\text { Professionally } \\
\text { Active }\end{array}$ \\
\hline $\begin{array}{l}\text { Margaret } \\
\text { Ledford }\end{array}$ & $45-49$ & Single & 0 & 0 years & 22 years & Graduate & $\begin{array}{l}\text { National } \\
\text { State } \\
\text { District/Local } \\
\end{array}$ \\
\hline $\begin{array}{l}\text { Whitney } \\
\text { Calhoun } \\
\end{array}$ & $40-44$ & Married & \begin{tabular}{|l|}
1 high school \\
1 college
\end{tabular} & 1 year & 19 years & Graduate & \begin{tabular}{|l|} 
State \\
District/Local
\end{tabular} \\
\hline $\begin{array}{l}\text { Jeanette } \\
\text { Golden } \\
\end{array}$ & $35-39$ & Married & $\begin{array}{l}2 \text { elementary } \\
\text { school }\end{array}$ & $21 / 2$ years & 4 years & Graduate & $\begin{array}{l}\text { State } \\
\text { District/Local }\end{array}$ \\
\hline $\begin{array}{l}\text { Elizabeth } \\
\text { Martin }\end{array}$ & $55-59$ & Married & $\begin{array}{l}1 \text { high school } \\
3 \text { adult } \\
\end{array}$ & 0 years & 8 years & Undergraduate & \begin{tabular}{|l|} 
State \\
District/Local
\end{tabular} \\
\hline \begin{tabular}{|l|} 
Ruth \\
Parker \\
\end{tabular} & $55-59$ & Married & \begin{tabular}{|l}
1 college \\
1 adult \\
\end{tabular} & 6 years & 27 years & Graduate & \begin{tabular}{|l} 
State \\
District/Local
\end{tabular} \\
\hline \begin{tabular}{|l|} 
Jane \\
Brown \\
\end{tabular} & $50-54$ & Single & $\begin{array}{l}1 \text { college } \\
1 \text { adult } \\
\end{array}$ & 17 years & 7 years & Graduate & \begin{tabular}{|l} 
State \\
District/Local
\end{tabular} \\
\hline $\begin{array}{l}\text { Anna } \\
\text { O'Brien }\end{array}$ & $40-44$ & Married & 1 high school & 12 years & 8 years & Graduate & \begin{tabular}{|l} 
State \\
District/Local
\end{tabular} \\
\hline \begin{tabular}{|l|} 
Brenda \\
West \\
\end{tabular} & $40-44$ & Married & 0 & 11 years & 11 years & Graduate & \begin{tabular}{|l} 
State \\
District/Local
\end{tabular} \\
\hline $\begin{array}{l}\text { Hazel } \\
\text { Greene } \\
\end{array}$ & $40-44$ & Single & 0 & 0 years & 22 years & Undergraduate & \begin{tabular}{|l|} 
State \\
District/Local
\end{tabular} \\
\hline $\begin{array}{l}\text { Amanda } \\
\text { Robbins } \\
\end{array}$ & $50-54$ & Married & 2 adult & 21 years & 6 years & Graduate & \begin{tabular}{|l|} 
State \\
District/Local
\end{tabular} \\
\hline $\begin{array}{l}\text { Martha } \\
\text { Mallory }\end{array}$ & $40-44$ & Single & 2 high school & $\begin{array}{l}1 \text { year, } \\
\text { part-time }\end{array}$ & 21 years & Graduate & $\begin{array}{l}\text { State } \\
\text { District/Local }\end{array}$ \\
\hline $\begin{array}{l}\text { Ellen } \\
\text { Hardy } \\
\end{array}$ & $35-39$ & Married & \begin{tabular}{|l|}
1 elementary \\
school \\
1 middle school
\end{tabular} & 0 years & 4 years & Undergraduate & $\begin{array}{l}\text { State } \\
\text { District/Local } \\
\end{array}$ \\
\hline $\begin{array}{l}\text { Anita } \\
\text { Cox }\end{array}$ & $50-54$ & Married & 1 adult & $161 / 2$ years & $12 \frac{1}{2}$ years & Graduate & \begin{tabular}{|l|} 
State \\
District/Local \\
\end{tabular} \\
\hline $\begin{array}{l}\text { Ann Marie } \\
\text { Johns } \\
\end{array}$ & $40-44$ & Married & 2 preschool & 15 years & 4 years & Graduate & \begin{tabular}{|l|} 
State \\
District/Local
\end{tabular} \\
\hline $\begin{array}{l}\text { Suzanne } \\
\text { Clayton }\end{array}$ & $45-49$ & Married & 0 & 1 year & 27 years & Undergraduate & \begin{tabular}{|l} 
State \\
District/Local
\end{tabular} \\
\hline $\begin{array}{l}\text { Julia } \\
\text { Stone }\end{array}$ & $50-54$ & Married & 2 adult & 13 years & 11 years & Graduate & \begin{tabular}{|l|} 
State \\
District/Local \\
\end{tabular} \\
\hline $\begin{array}{l}\text { Marla } \\
\text { Evans }\end{array}$ & $35-39$ & Married & 0 & 17 years & 2 years & Graduate & \begin{tabular}{|l|} 
State \\
District/Local
\end{tabular} \\
\hline $\begin{array}{l}\text { Sidney } \\
\text { George }\end{array}$ & $45-49$ & Married & $\begin{array}{l}1 \text { high school } \\
1 \text { college }\end{array}$ & 5 years & 10 years & Graduate & \begin{tabular}{|l} 
State \\
District/Local
\end{tabular} \\
\hline
\end{tabular}

\section{REFERENCES}

Apple, M. W. (1986). Teachers and texts: A political economy of class and gender relations in education. New York: Routledge \& Kegan Paul.

Bank, J. (1994). Directory of Kentucky's Libraries and Archives: 1994-1995. Frankfort, KY: Division of Field Services Kentucky Department of Libraries and Archives.

Biklen, S. K. (1995). School work: Gender and the cultural construction of teaching. New York: Teachers College Press.

Hannigan, J. A. (1994). A feminist standpoint for library and information science education. Journal of Education for Library and Information Science, 35, 297-319.

Hargreaves, A. (1994). Changing teachers, changing times: Teachers' work and culture in the postmodern age. New York, NY: Teachers College Press. 
Hargreaves, A. \& Fullan, M. G. (1992). Introduction. In A. Hargreaves and M. G. Fullan (Eds.), Understanding teacher development. New York, NY: Teachers College Press. (pp. 1-19).

Huberman, M. (1993). The lives of teachers. (J. Neufeld, Trans.). New York, NY: Teachers College Press. (Original work published 1989).

Huberman, M. (1995). Working with life-histories narratives. In H. McEwan \& K. Egan (Eds.), Narrative in teaching, learning, and research. (pp. 127-265). New York: Teachers College Press.

Huberman, M, \& Grounauer, M. (1993). Teachers' motivations and satisfactins. In M. Huberman, The lives of teachers. (J. Neufeld, Trans.). New York, NY: Teachers College Press. (Original work published 1989.) (pp. 109-137).

Hug, W. E. (1981). Critical issues in school media program. In J. W. Brown \& S. N.Brown (Eds.), Educational media yearbook 1981. (pp. 50-58). Littleton, CO: Libraries Unlimited. Lamphere, L. (1985). Bringing the family to work: Women's culture on the shop floor. Feminist Studies, 3, 519-540.

Lortie, D. C. (1975). Schoolteacher: A sociological study. Chicago, IL: University of Chicago Press.

Zipkowitz, F. (1995). After graduation day: The market for new librarians. School Library Journal, 41 (12), 13. 